\title{
Pathogens Causing Anthracnose and Fruit Rots of Coffee Associated with the Coffee Berry Borer and the Entomopathogenic Fungus Beauveria bassiana in Puerto Rico
}

\author{
Luz M. Serrato-Diaz, ${ }^{1,2, \dagger}$ Yobana A. Mariño, ${ }^{1}$ and Paul Bayman ${ }^{1}$ \\ ${ }^{1}$ Department of Biology, University of Puerto Rico-Río Piedras, P.O. Box 23360, San Juan, PR 00931-3360, U.S.A. \\ ${ }^{2}$ U.S. Department of Agriculture-Agriculture Research Service-Tropical Agriculture Research Station (TARS), 2200 P.A. Campos Ave., Ste. \\ 201, Mayagüez, PR 00680-5470, U.S.A. \\ Accepted for publication 24 April 2020.
}

\begin{abstract}
Fruit rots reduce coffee production worldwide. Eight Colletotrichum species have been reported to cause coffee fruit rots; the most important is C. kahawae, the cause of coffee berry disease (CBD) in Africa. It is unknown whether these fruit rot pathogens can be dispersed by the coffee berry borer (CBB, Hypothenemus hampei) or whether Beauveria bassiana (a natural enemy of CBB) might reduce coffee fruit rots. We identified pathogens causing coffee fruits rots in Puerto Rico and evaluated whether B. bassiana reduced fruit rot and whether CBB could disperse pathogens. A total of 2,333 coffee fruit with CBB damage were collected; of these, 1,197 had visible growth of B. bassiana. C. fructicola, $C$. siamense, $C$. theobromicola, and $C$. tropicale were isolated and

B. bassiana had significantly less fruit rot than untreated fruit, suggesting $B$. bassiana can protect against fruit rot. To test whether $B$. bassiana had a protective effect, $B$. bassiana and Colletotrichum were coinoculated on coffee fruit. Fruit inoculated with both $B$. bassiana and Colletotrichum had significantly less rot than fruit inoculated with Colletotrichum alone. To test if CBBs dispersed the pathogens, CBBs were exposed to Colletotrichum conidia and placed on green fruit, which resulted in fruit rot. This study identifies new pathogens causing coffee fruit rot, shows that $C$. kahawae is not the only Colletotrichum that attacks green fruits, suggests a role for $B$. bassiana in disease management and demonstrates $\mathrm{CBB}$ can disperse the pathogens.
\end{abstract} identified from the fruit using morphological traits and phylogeny of three nuclear genes. All four species caused internal and external rot after inoculation of healthy green coffee fruit. Coffee fruit treated with
Keywords: anthracnose, biological control, coffee berry disease, Colletotrichum, disease control and pest management, mycology
Coffee berry disease (CBD) is among the most important diseases of coffee (Coffea arabica L.) (Talhinhas et al. 2017). On green coffee fruit, lesions of CBD are dark brown, necrotic and sunken; the fruits eventually become mummified (Fig. 1) (Gaitán et al. 2015). The literature states that Colletotrichum kahawae subsp. kahawae Waller and Bridge is the sole pathogen and that the disease is limited to areas of coffee cultivation at high altitudes in Africa (Batista et al. 2017; Weir et al. 2012). The disease can cause yield losses up to $80 \%$ in Kenya, Angola, Cameroon, and Malawi (Mignucci et al. 1985; Nguyen et al. 2010; Omondi et al. 2001; Sreenivasaprasad et al. 1993; Vermeulen 1970; Waller et al. 1993). CBD management relies on fungicides and resistant cultivars (Birikunzira 2000; Etana 2018; Van der Vossen et al. 1976).

C. kahawae subsp. kahawae belongs to the C. gloeosporioides complex (Weir et al. 2012). This complex also includes the subspecies $C$. kahawae subsp. cigarro, not pathogenic to coffee

${ }^{\dagger}$ Corresponding author: L. M. Serrato-Díaz; luz.serrato@usda.gov

Funding: Support was provided by the U.S. Department of Agriculture Corporative Agreement 58-1245-4-083, and the Puerto Rico Science and Technology Research Trust. Sequencing was provided by the University of Puerto Rico SGF, supported by NCRR AABRE grant number P20 RR16470).

*The $\boldsymbol{e}$-Xtra logo stands for "electronic extra" and indicates that two supplementary tables are published online.

The author(s) declare no conflict of interest.

This article is in the public domain and not copyrightable. It may be freely reprinted with customary crediting of the source. The American Phytopathological Society, 2020. fruit, and 20 other species of Colletotrichum. Several other species in the $C$. gloeosporioides complex have been reported to cause anthracnose diseases on coffee in other countries: $C$. capsici, C. fructicola, C. gloeosporioides, and $C$. siamense as well as C. acutatum and C. boninense (Table 1) (Hocking 1966; Mignucci et al. 1985; Nguyen et al. 2010; Omondi et al. 2001; Prihastuti et al. 2009; Sreenivasaprasad et al. 1993; Vermeulen 1970; Waller et al. 1993). In Puerto Rico, only C. gloeosporioides has been reported to cause anthracnose on coffee, infecting various organs including fruit (Mignucci et al. 1985). No reports on control have been published in Latin America, except on resistance of hybrids of Coffea arabica and Coffea canephora Pierre ex A. Froehner to Colletotrichum and coffee leaf rust in Colombia (Maldonado et al. 2017). Also, fungicides and fertilization were reported to reduce anthracnose on coffee fruit in Puerto Rico (Mignucci et al. 1985).

In this report we use the term CBD to refer solely to the disease caused by $C$. kahawae in Africa. Symptoms caused by CBD are typical of an anthracnose, and other Colletotrichum spp. pathogens cause anthracnose-like symptoms on coffee fruit elsewhere in the world (though very few studies mention anthracnose on green fruit). Lesions caused by Colletotrichum are typically dark, sunken, and produce acervuli (Agrios 1997).

The coffee berry borer (CBB) Hypothenemus hampei (Ferrari) is the most devastating pest of coffee worldwide (Damon 2000; Infante et al. 2014; Vega et al. 2009, 2015). Damage is caused when the adult female bores into the fruit to deposit eggs; its larvae then feed on the endosperm (Damon 2000; Vega et al. 2006, 2009). High levels of CBB infestation (up to 50 to $90 \%$ ) have been reported in Colombia, Jamaica, Malaysia, Mexico, Tanzania, and Uganda (Vega 2004). In Puerto Rico, CBB infestation ranged from 0 to $95 \%$ depending on year, altitude, and temperature (Mariño et al. 2017a). Integrated pest management strategies 
including insecticides, biological control using natural enemies, and cultural control have been reported to reduce CBB populations (Aristizábal et al. 2017; Jaramillo et al. 2006; Mariño et al. 2017a).

The most commonly used biological control agent against $\mathrm{CBB}$ is the fungus Beauveria bassiana (Costa et al. 2002; De La Rosa et al. 2000; Haraprasad et al. 2001; Wraight et al. 2018). B. bassiana also inhibits in vitro growth of several phytopathogenic fungi including Colletotrichum (Ownley et al. 2010; Sahab 2012; Sanivada and Challa 2014). Other studies have demonstrated a protective effect of $B$. bassiana in vivo against Fusarium oxysporum f. sp. lycopersici race 3 and Rhizoctonia solani (Culebro-Ricaldi et al. 2017; Ownley et al. 2004; Ownley et al. 2008).

We hypothesize that more than one species of Colletotrichum causes anthracnose diseases of green coffee fruit, that they may be responsible for causing different degrees of internal versus external rots of coffee fruit, and that infection with $B$. bassiana can protect coffee fruit from infection by the causal pathogens. Furthermore, CBB may be a dispersal agent of these pathogens. Also, we hypothesized that some of the pathogens of coffee fruit in Puerto Rico cause symptoms indistinguishable to those attributed to CBD in Africa. Thus, this study has four objectives: (i) to identify the causal agents responsible for symptoms of anthracnose on coffee fruit in Puerto Rico; (ii) to explore the interactions among anthracnose, $\mathrm{CBB}$, and B. bassiana; (iii) to differentiate between pathogens that may cause external or internal symptoms in coffee fruit; and (iv) to interpret the results in light of the debate on identity and distribution of CBD.

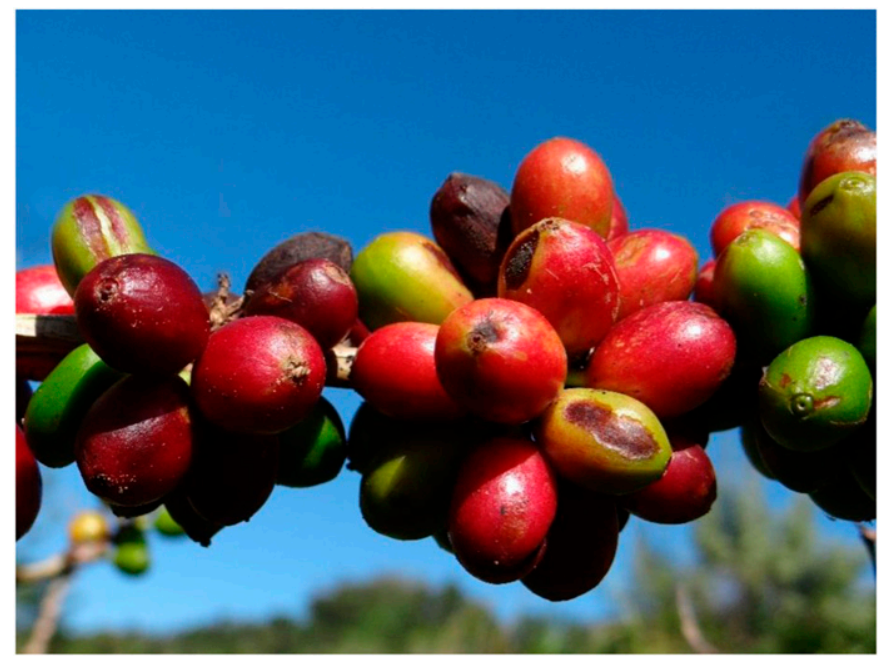

Fig. 1. Coffee fruit rot on fruit of Coffea arabica 'Limaní'. Brown and red sunken lesions show early stages of the disease; black, mummified fruit (upper center) show advanced stages. Green fruit as well as mature fruit are infected. Several fruits show holes caused by the coffee berry borer, which bores the hole in the fruit to deposit its eggs.

\section{MATERIALS AND METHODS}

Collection of plant material and isolation of fungi. Surveys were conducted in 2016 and 2017 from August to December (when coffee fruit are developing and maturing in Puerto Rico). A total of 2,333 full-sized green coffee fruits (Coffea arabica 'Limaní' and 'Catuaí') with entry holes of CBB were collected from commercial and experimental orchards in Puerto Rico. Two of the orchards were in Adjuntas $\left(18^{\circ} 10^{\prime} 28.73^{\prime \prime} \mathrm{N}\right.$, $66^{\circ} 44^{\prime} 35.83^{\prime \prime} \mathrm{W}, \quad 510 \mathrm{~m}$ above sea level (m.a.s.l) and $18^{\circ} 10^{\prime} 12.42^{\prime \prime} \mathrm{N}, 66^{\circ} 47^{\prime} 43.21^{\prime \prime} \mathrm{W}, 636$ m.a.s.1.), one in Ciales $\left(18^{\circ} 18^{\prime} 12.24^{\prime \prime} \mathrm{N}, 66^{\circ} 33^{\prime} 7.55^{\prime \prime} \mathrm{W}, 373\right.$ m.a.s.l.), and one in Utuado $\left(18^{\circ} 15^{\prime} 51.52^{\prime \prime} \mathrm{N}, 66^{\circ} 47^{\prime} 14.61^{\prime \prime} \mathrm{W}, 580\right.$ m.a.s.l). Selected fruit had no external symptoms of fruit rot. Of the 2,333 fruit with CBB damage, 1,197 had white fungal growth typical of sporulating B. bassiana colonies collected from dead CBBs in the entrance hole or on the fruit adjacent to the hole where the CBB entered. These colonies were cultured and examined by light microscopy to confirm the morphology was congruent with that of B. bassiana. Coffee fruit were cut in half and disease severity was evaluated by visually estimating the percentage of the cut surface that was rotted, in comparison with the scale in Figure 2.

Pieces of coffee fruit with internal lesions were surface-sterilized in $70 \%$ ethanol, followed by $1 \%$ sodium hypochlorite, rinsed in sterile distilled water (1 min each) and placed in Petri plates on potato dextrose agar (PDA) amended with streptomycin at 0.125 $\mathrm{g} /$ liter and ampicillin at $0.25 \mathrm{~g} /$ liter. Cultures were incubated at $23^{\circ} \mathrm{C}$ with an approximately $12 \mathrm{~h}$ photoperiod for 8 days. Pure cultures were obtained by hyphal tip transfer. Isolates that sporulated were identified to genus, using standard morphological characters: colony color and texture, growth rate, size and shape of conidia, formation of structures (pycnidia, acervuli, perithecia, sporodochia, among others) and size of asci and ascospores if present (Barnett and Hunter 1998).

Morphological characterization of Colletotrichum. Fungal colonies suspected of being Colletotrichum spp. were transferred to PDA and incubated for 8 days at $23^{\circ} \mathrm{C}$ with an approximately $12 \mathrm{~h}$ photoperiod. Isolates were grouped in morphospecies based on colony color and texture, shape and size of conidia and appressoria, formation of perithecia, and size of asci and ascospores, if produced. A total of 50 measurements were taken per isolate for each morphological trait that was assessed microscopically at $100 \times$ or $400 \times$ (depending on the trait). The traits were used to identify the Colletotrichum species using taxonomic keys (Weir et al. 2012).

DNA extraction, PCR, and sequencing. Fourteen representative Colletotrichum isolates (including representatives of all morphospecies) were selected and grown in potato dextrose broth (PDB) under the conditions described above, DNA was extracted from approximately 0.1 to $0.25 \mathrm{~g}$ of mycelium using a Dneasy Plant Mini Kit (Qiagen, Valencia, CA). Three gene regions commonly used to identify Colletotrichum species were amplified by PCR using an Amplitaq Gold (Applied Biosystems, Waltham, MA) DNA polymerase according to Weir et al. (2012). The gene regions amplified were: the internal transcribed spacer (ITS)

TABLE 1. Species of Colletotrichum causing anthracnose of coffee fruit and coffee berry disease worldwide

\begin{tabular}{|c|c|c|}
\hline Colletotrichum species & Country & Reference \\
\hline C. acutatum & Vietnam, Papua New Guinea & Nguyen et al. 2010; Kenny et al. 2012 \\
\hline C. boninense & Vietnam & Nguyen et al. 2010 \\
\hline C. capsici & Vietnam & Nguyen et al. 2010 \\
\hline C. coffeanum & East Africa, Kenya & Hocking 1966; Vermeulen 1970 \\
\hline C. fructicola & Thailand & Prihastuti et al. 2009 \\
\hline C. gloeosporioides & Puerto Rico, Vietnam, Papua New Guinea & $\begin{array}{l}\text { Mignucci et al. 1985; Nguyen et al. 2010; } \\
\text { Kenny et al. } 2012\end{array}$ \\
\hline C. kahawae & Kenya, Angola, Cameroon, and Malawi & Waller et al. 1993; Omondi et al. 2001 \\
\hline C. siamense & Thailand & Prihastuti et al. 2009 \\
\hline
\end{tabular}


ITS1-5.8S-ITS2 region of the nuclear ribosomal DNA, part of the chitin synthase (CHS) gene, and part of the glyceraldehyde 3phosphate dehydrogenase (GAPDH) gene (Weir et al. 2012). The ITS region was amplified using primers ITS1/ITS4 (White et al. 1990). Partial sequences of the CHS and GADPH genes were amplified using primers CHS-79F/CHS-345R (Carbone and Kohn 1999) and GDF/GDR (Templeton et al. 1992), respectively. Amplicons ranged from 300 to $550 \mathrm{bp}$. PCR products were purified using a QIAQuick PCR Kit (Qiagen) and sequenced at the Sequencing and Genotyping Facility at the University of Puerto Rico (UPR, San Juan, PR). Sequences were edited using Sequencher (version 5.0, Gene Codes Corporation, MN) and deposited in NCBI GenBank (Table 2).

Phylogenetic inference. Phylogenetic analysis included 71 ingroup taxa (Supplementary Table S1), with C. boninense ex-types MAFF306094 and MAFF305972 as outgroups according to Weir et al. (2012). Both Colletotrichum isolates from the field and those recovered from pathogenicity experiments were included in the analysis. Sequences were aligned using SATé (Katoh and Standley 2013) and MAFFT with RAxML for the tree estimator with 10 iterations. The three genes were concatenated using Sequence Matrix to give 1,232 characters including alignment gaps. Maximum likelihood trees were constructed to infer the phylogeny of Colletotrichum spp. using RAxML with GTRCAT as the default model, 25 gamma categories and the automatic bootstrap MRE implemented in CIPRES Science Gateway portal (Miller et al. 2010; Stamatakis 2006a, b).

Location of field experiments and plant material. All field experiments described below were conducted at the UPR Agricultural Experiment Station in Adjuntas, Puerto Rico, a center of coffee research and production. The experiments were conducted in a plot planted with cultivar Limaní. The plot is located at $18^{\circ} 10^{\prime} 12.24^{\prime \prime} \mathrm{N}, 66^{\circ} 47^{\prime} 43.21^{\prime \prime} \mathrm{W}$, with an altitude of 434 m.a.s.l. and mean temperature of $22.5^{\circ} \mathrm{C}$. Coffee plants were grown under partial shade of Gliricidia sepium (mother-of-cocoa, Fabaceae: Faboideae). Lab experiments described below were conducted at the UPR-Río Piedras location. Both lab and field experiments were repeated (2017 and 2018). For all experiments, we selected fullsized, green coffee fruit approximately 80 days old (Gallardo and González 2015).

Inoculations with Colletotrichum spp. only. Pathogenicity tests were used to determine whether the Colletotrichum isolates described above (Table 2) were pathogens or saprotrophs, and to determine if damage caused by $\mathrm{CBB}$ could be an entry point for Colletotrichum spp. to infect coffee fruit. Since there is often considerable variation in aggressiveness within species (Balardin

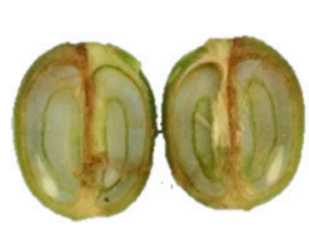

Healthy

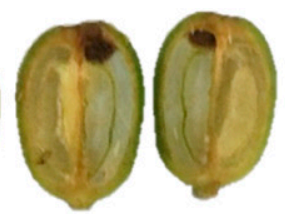

$5 \%$
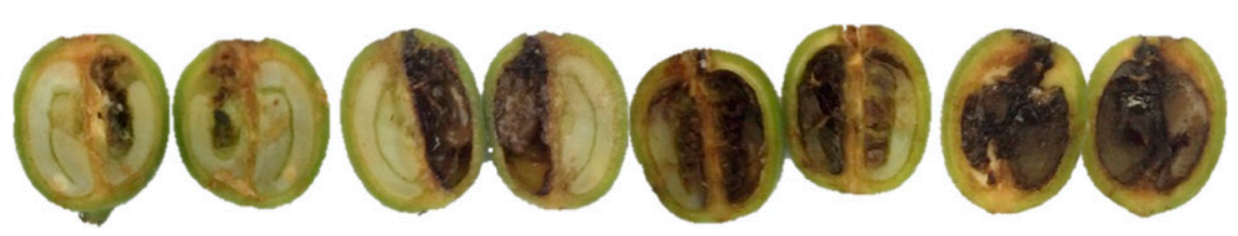

$25 \%$
$50 \%$
$80 \%$
$100 \%$

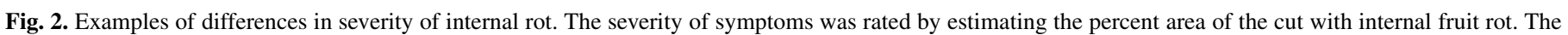
two halves of each fruit are shown.

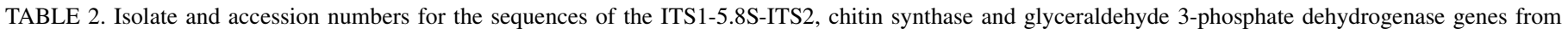
various Colletotrichum isolates collected from internal rots in coffee fruit in Puerto Rico

\begin{tabular}{|c|c|c|c|c|c|}
\hline \multirow[b]{2}{*}{ Isolate } & \multirow[b]{2}{*}{ Species } & \multirow[b]{2}{*}{ Isolate source } & \multicolumn{3}{|c|}{ GenBank accession numbers } \\
\hline & & & ITS & CHS & GADPH \\
\hline $\mathrm{C} 16 \mathrm{P}$ & Colletotrichum fructicola & Field & MK790665 & MK796193 & MK796222 \\
\hline C38PP & Colletotrichum fructicola & Recovered-pathogenicity test & MK790664 & MK796192 & MK796221 \\
\hline $\mathrm{C} 2 \mathrm{P}$ & Colletotrichum siamense & Field & MK790642 & MK796170 & MK796199 \\
\hline $\mathrm{C} 3 \mathrm{P}$ & Colletotrichum siamense & Field & MK790643 & MK796171 & MK796200 \\
\hline C13PA & Colletotrichum siamense & Field & MK790647 & MK796175 & MK796204 \\
\hline C13PC & Colletotrichum siamense & Field & MK790648 & MK796176 & MK796205 \\
\hline $\mathrm{C} 14 \mathrm{P}$ & Colletotrichum siamense & Field & MK790649 & MK796177 & MK796206 \\
\hline C17P & Colletotrichum siamense & Field & MK790670 & MK796198 & MK796227 \\
\hline $\mathrm{C} 19 \mathrm{P}$ & Colletotrichum siamense & Field & MK790650 & MK796178 & MK796207 \\
\hline C111P & Colletotrichum siamense & Field & MK790652 & MK796180 & MK796209 \\
\hline C54PP & Colletotrichum siamense & Recovered-pathogenicity test & MK790655 & MK796183 & MK796212 \\
\hline C62PP & Colletotrichum siamense & Recovered-pathogenicity test & MK790656 & MK796184 & MK796213 \\
\hline C63PP & Colletotrichum siamense & Recovered-pathogenicity test & MK790657 & MK796185 & MK796214 \\
\hline C88PP & Colletotrichum siamense & Recovered-pathogenicity test & MK790658 & MK796186 & MK796215 \\
\hline C89PP & Colletotrichum siamense & Recovered-pathogenicity test & MK790659 & MK796187 & MK796216 \\
\hline C124PP & Colletotrichum siamense & Recovered-pathogenicity test & MK790660 & MK796188 & MK796217 \\
\hline C136PP & Colletotrichum siamense & Recovered-pathogenicity test & MK790661 & MK796189 & MK796218 \\
\hline $\mathrm{C} 162 \mathrm{PP}$ & Colletotrichum siamense & Recovered-pathogenicity test & MK790668 & MK796196 & MK796225 \\
\hline C9P & Colletotrichum theobromicola & Field & MK790645 & MK796173 & MK796202 \\
\hline C12PA & Colletotrichum theobromicola & Field & MK790646 & MK796174 & MK796203 \\
\hline C120P & Colletotrichum theobromicola & Field & MK790653 & MK796181 & MK796210 \\
\hline $\mathrm{C} 122 \mathrm{P}$ & Colletotrichum theobromicola & Field & MK790654 & MK796182 & MK796211 \\
\hline C51PP & Colletotrichum theobromicola & Recovered-pathogenicity test & MK790669 & MK796197 & MK796226 \\
\hline C53PP & Colletotrichum theobromicola & Recovered-pathogenicity test & MK790667 & MK796195 & MK796224 \\
\hline C67PP & Colletotrichum theobromicola & Recovered-pathogenicity test & MK790662 & MK796190 & MK796219 \\
\hline C68PP & Colletotrichum theobromicola & Recovered-pathogenicity test & MK790663 & MK796191 & MK796220 \\
\hline $\mathrm{C} 20 \mathrm{P}$ & Colletotrichum tropicale & Field & MK790651 & MK796179 & MK796208 \\
\hline C165PP & Colletotrichum tropicale & Recovered-pathogenicity test & MK790666 & MK796194 & MK796223 \\
\hline
\end{tabular}


et al. 1997; Denoyes-Rothan et al. 2003; Hong et al. 2008; Ratanacherdchai et al. 2007), 16 Colletotrichum isolates representing four species were selected.

In the field, each isolate was inoculated on 12 coffee fruit (Coffea arabica 'Limaní') per branch, on three different branches per plant, and on five plants, for a total of 180 fruit inoculated per isolate. Each fruit was marked, and a hole made using a sterilized wire dissecting needle ( 0.5 to $0.8 \mathrm{~mm}$ diameter) to mimic CBB damage. Subsequently, coffee fruit were inoculated using a Pasteur pipette with approximately $10 \mu \mathrm{l}$ of a suspension of $4 \times 10^{6} \mathrm{conidia} / \mathrm{ml}$ from 8-day-old pure cultures of Colletotrichum spp. grown on PDA as previously described. Untreated controls were inoculated with sterilized distilled water only. Inoculated coffee branches were covered with plastic bags for 15 days to maintain humidity and to prevent access to CBB. Fruit rot was evaluated at 15 days after inoculation (DAI) (a period sufficient for fruit to become diseased but not sufficient for other fungi to invade). Percent internal and external fruit rot was estimated visually: external fruit rot was evaluated before fruit were cut in half to evaluate internal fruit rot as described above (Fig. 2). In both cases severity of fruit rot was estimated based on the percentage scale ( 0 to $100 \%)$, where 0 represents healthy fruit and $100 \%$ indicates the entire fruit was rotted.

Diseased tissue was plated on PDA to complete Koch's postulates (Agrios 1997). Fourteen isolates were recovered from pathogenicity tests, identified by grouping into morphotypes and sequencing of the three genes as described above to determine that the isolates recovered were the same as those used for the inoculations.

Dual inoculations with Colletotrichum spp. and B. bassiana. To test the hypothesis that infection by $B$. bassiana could protect coffee fruit from rot caused by Colletotrichum, pathogenicity tests were conducted in the field and laboratory. $C$. siamense and $C$. tropicale were chosen for inoculation because $C$. siamense was the most common species isolated from the coffee fruit, while $C$. tropicale caused the most severe external rot; in both field and laboratory experiments a mixture of $2 \times 10^{6}$ conidia of each species was applied using a Pasteur pipette with $10 \mu \mathrm{l}$ of a suspension following the procedure described above.

Each test included five treatments and 300 coffee fruit (Coffea arabica 'Limaní') (60 fruit per treatment). Three treatments were negative controls (fruit with holes to mimic CBB damage inoculated with $B$. bassiana [T1], fruit with holes alone [T2], and intact fruit [T3]), one treatment was a positive control (fruit with holes and inoculated with Colletotrichum [T4]), and one treatment was the experimental treatment (fruit with holes inoculated with B. bassiana and Colletotrichum [T5]) (Table 3). For the field experiments, five typical coffee plants were selected, and five branches on each plant were randomly assigned to treatments $\mathrm{T} 1$ to T5; any CBB perforated or diseased fruit were removed from branches to avoid cross contamination. Twelve apparently healthy, full-sized green fruit per branch were chosen and marked, and a hole was made with a sterilized wire dissecting needle $(0.5 \mathrm{~mm}$ diameter $)$ to mimic CBB damage.

Inoculation of fruit with $B$. bassiana was performed 2 days before the inoculation with Colletotrichum spp. B. bassiana isolate N5 was used. It was originally isolated from coffee fruit in Adjuntas, PR and was chosen because it is highly aggressive to CBB (unpublished observations); isolate N5 is stored in culture collections at UPR-RP and at the U.S. Department of Agriculture-Agricultural Research Service Mycology and Nematology Genetic Diversity and Biology Laboratory, Beltsville, MD. Preparation and inoculation of $B$. bassiana was the same as described above for Colletotrichum.

For laboratory tests, three coffee branches containing at least 12 apparently healthy, full-sized green fruit were detached from the coffee bushes and placed in Erlenmeyer flasks with distilled water (to prevent wilting) and inoculated as previously described. At 15 DAI, fruit were cut in half and the percent severity of fruit rot was visually estimated for each fruit and diseased tissue was plated on PDA to complete Koch's postulates.

CBB as a dispersal agent of Colletotrichum. The hypothesis that $\mathrm{CBB}$ could disperse Colletotrichum to coffee fruit was tested in the laboratory and in the field. For laboratory experiments groups of adult female CBBs were exposed to a suspension of conidia of $C$. siamense and $C$. tropicale (mixed as described above). For field experiments, the four species of Colletotrichum were tested separately.

CBBs were grown on the artificial diet CENIBROCA as previously described (Mariño et al. 2017b). Adult females were surface-disinfected by submersion in $1 \%$ sodium hypochlorite with $0.02 \%$ Tween 80 , followed by two rinses with sterilized water for $1 \mathrm{~min}$ each. For both lab and field experiments the insects were surface-inoculated with spores of Colletotrichum spp. A filter paper in a Petri dish was impregnated with $500 \mu \mathrm{l}$ of a conidial suspension of one species of Colletotrichum at a time (field experiments) or a 50:50 mix (laboratory experiments) of $C$. siamense and $C$. tropicale $\left(4 \times 10^{6}\right.$ conidia $/ \mathrm{ml}$ in both cases). The $\mathrm{CBBs}$ were placed in the Petri dishes for $1 \mathrm{~h}$.

For the laboratory tests, coffee branches with fruit as described for the previous experiment were placed in Erlenmeyer flasks with distilled water. There were three replicate branches for each treatment. The treatments were CBBs previously inoculated with conidia of Colletotrichum spp. (T1), CBBs not inoculated with conidia of Colletotrichum spp. (T2), CBBs exposed to sterilized distilled water only and intact fruit, a negative control (T3), and fruit manually perforated to mimic $\mathrm{CBB}$ damage and subsequently inoculated with Colletotrichum spp., a positive control (T4). In the field, five coffee plants were selected, and three replicate branches with at least 20 apparently healthy, full-sized green fruit were used per Colletotrichum species. Experiments included five treatments: CBBs not exposed to conidia of Colletotrichum spp., a negative control (T1), CBBs exposed to conidia of $C$. fructicola (T2), CBBs exposed to conidia of $C$. siamense (T3), CBBs exposed to conidia of C. tropicale (T4), and CBBs exposed to conidia of $C$. theobromicola (T5). In both the laboratory and the field experiments, any CBB perforated or diseased fruit were removed from branches to avoid cross contamination. Forty $\mathrm{CBBs}$ exposed to the conidial suspension were placed on each branch and the branches covered with plastic bags to maintain humidity and prevent the CBBs from escaping. Percent fruit rot was evaluated at $15 \mathrm{DAI}$; diseased fruit tissue and $\mathrm{CBBs}$ were plated on PDA to confirm that the pathogens were the same as the fungi that were inoculated.

Statistical analysis. One-way analysis of variance (ANOVA) was performed to determine significance of treatment effects, and

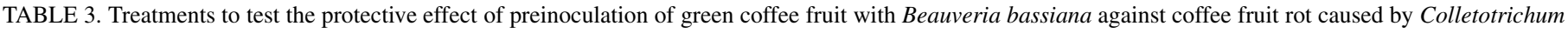
spp.

\begin{tabular}{|c|c|c|c|}
\hline Treatment & Bored & B. bassiana & Colletotrichum spp. \\
\hline $\mathrm{T} 1$ : Bored fruit $^{\mathrm{a}}+$ Beauveria bassiana & $\mathrm{X}$ & $\mathrm{X}$ & \\
\hline T2: Bored fruit (negative control) & $\mathrm{X}$ & & \\
\hline \multicolumn{4}{|l|}{ T3: Intact fruit (negative control) } \\
\hline $\mathrm{T} 4$ : Bored fruit + Colletotrichum spp. & $\mathrm{X}$ & & $\mathrm{X}$ \\
\hline T5: Bored fruit + Colletotrichum spp. $+B$. & & & \\
\hline bassiana (experimental) & $\mathrm{X}$ & $\mathrm{X}$ & $\mathrm{X}$ \\
\hline
\end{tabular}

a Bored fruit: each fruit was penetrated with a $0.5 \mathrm{~mm}$ wire needle to simulate coffee berry borer damage. 
Tukey's honest significant differences (HSD) post hoc test $(\alpha=$ 0.05 ) was used to explore the differences between the mean values of the treatments (severity of fruit rot among Colletotrichum species or among inoculation treatments). All analyses were calculated using R (R Core Team 2017). ANOVAs tests were performed with the $\operatorname{aov}()$ function and pairwise post hoc tests with TukeyHSD() function with a confidence interval of $95 \%$. Severity data on fruit rot were transformed using the Bliss angular transformation (Bliss 1937) to fulfill requirements of normality and homogeneity of variance. Back transformed mean fruit rot severity values are presented.

\section{RESULTS}

Fungal diversity and rot in coffee fruit with and without B. bassiana. A total of 323 fungi in 11 genera were isolated from the rotted internal tissues of the sampled coffee fruit. The most common fungi were $B$. bassiana (175 isolates) followed by Fusarium spp. (72 isolates) and Colletotrichum spp. (49 isolates). Other genera were isolated less frequently ( $<5$ isolates each): Pestalotiopsis, Phomopsis, Aspergillus, Guignardia, Cladosporium, and Penicillium (Supplementary Table S2).

Coffee fruit with sporulating colonies of $B$. bassiana had significantly less fruit rot than coffee fruit without $B$. bassiana $(F=$ 126.06, $P<0.0001$ ), suggesting $B$. bassiana could be a potential biological control agent against anthracnose (Fig. 3). The result formed the basis for subsequent experiments.

Morphological identification of Colletotrichum spp. Four species belonging to the $C$. gloeosporioides complex were isolated from rotted coffee fruit tissues and identified based on morphology (Weir et al. 2012).

C. fructicola. On PDA, colonies were gray with aerial mycelia. Conidia did not form acervuli in culture. Conidia $(n=50)$ were $13.9 \times 4.5 \mu \mathrm{m}$, one-celled, smooth-walled, hyaline, cylindrical to oblong, rounded at both ends. Appressoria were 6.5 to 8.5 in diameter. Perithecia were subglobose to ovoid, semi-immersed in PDA. Asci $(n=20)$ were $55 \times 10 \mu \mathrm{m}$, clavate, unitunicate, thinwalled and contained 8 ascospores. Ascospores $(n=50)$ were $10.9 \times$ $4.3 \mu \mathrm{m}$, one-celled, hyaline, slightly curved and rounded at both ends (Fig. 4A).

C. siamense. On PDA, colonies were grayish-white with aerial mycelium and conidial masses (acervuli visible in culture). Conidia $(n=50)$ were $15.2 \times 4.3 \mu \mathrm{m}$, one-celled, smooth-walled, hyaline, cylindrical to oblong, and rounded at both ends. Appressoria were 4.5 to $5.0 \mu \mathrm{m}$ in diameter, and perithecia were absent (Fig. 4B).

C. theobromicola. On PDA, colonies were grayish turning dark gray with age, with aerial mycelium. Conidia did not form acervuli in culture. Conidia $(n=50)$ were $15 \times 4.5 \mu \mathrm{m}$, subcylindrical to clavate. Appressoria were 7 to $10 \mu \mathrm{m}$ in diameter and perithecia were absent (Fig. 4C).

C. tropicale. On PDA, colonies were grayish-white with aerial mycelium. Conidia did not form acervuli in culture. Conidia $(n=$ 50) were $19.8 \times 5.3 \mu \mathrm{m}$, cylindrical, hyaline, straight, and rounded at both ends. Appressoria were 8 to $10 \mu \mathrm{m}$ in diameter and perithecia were absent (Fig. 4D).

C. kahawae was not isolated.

Phylogenetic inference. The best maximum likelihood tree clustered the Colletotrichum isolates in four clades corresponding to the species described above (Fig. 5). Of the 28 isolates of Colletotrichum sequenced, eight clustered with $C$. siamense (bootstrap support $[\mathrm{BS}]=61)$, four with $C$. theobromicola $(\mathrm{BS}=$ $99)$, one with $C$. fructicola $(\mathrm{BS}=83)$, and one with $C$. tropicale $(\mathrm{BS}=99)$.

Inoculations with Colletotrichum spp. alone. All four species of Colletotrichum tested (C. fructicola, $C$. siamense, $C$. theobromicola, and $C$. tropicale) were pathogenic on green coffee fruit, causing fruit rot. All four species caused both internal and external fruit rots at 15 DAI. With external rots, the epicarp turned from green to dark brown, in some cases with mycelial growth visible on the fruit surface. With the internal rots, the endosperm turned brown and water-soaked lesions were observed in the mesocarp (Fig. 6B). Fruit from untreated controls (inoculated with sterilized distilled water only) showed no symptoms of fruit rot.

With the external rots, significant differences in aggressiveness were observed among species $(F=6.98 ; P<0.0001)$. The most aggressive species was $C$. tropicale, followed by $C$. theobromicola, $C$. fructicola, and $C$. siamense, respectively. With the internal rots, differences among species were also significant $(F=11.0 ; P=$ 0.012); C. theobromicola and $C$. fructicola were the most aggressive species (Fig. 6A).

Phylogenetic analysis of species reisolated from the pathogenicity tests confirmed that they belonged to the same four Colletotrichum species that had been used for inoculation, fulfilling Koch's postulates (Figs. 5 and 6B).

Dual inoculations with Colletotrichum spp. and B. bassiana. In both laboratory and field experiments, coffee fruit inoculated with $B$. bassiana before inoculation with Colletotrichum (treatment T5) had significantly lower severity (percent rot per fruit) than fruit inoculated with Colletotrichum alone (positive controls, T4) (Fig. 7A and C; lab experiments: $F=16.30, P<0.0001$; field experiments: $F=15.74, P<0.0001)$. However, under field conditions the negative controls (T1 and T2) were not different from the positive controls (T4): there was growth of Fusarium spp., indicating that Fusarium also plays a role in coffee fruit rot and thus may complicate observations on the interaction between Colletotrichum spp. and B. bassiana (Fig. 7D). Colletotrichum was reisolated from fruit inoculated with Colletotrichum alone but not from fruit inoculated with both Colletotrichum and B. bassiana (except for 2 isolates recovered from a sample in a plastic bag that opened in the field, permitting entry of inoculum from outside). In the field, Fusarium was the most frequent fungal genus isolated from control fruit and fruit inoculated with Colletotrichum and B. bassiana (Fig. 7B and D).

CBB as a dispersal agent of Colletotrichum. In lab experiments, fruit damaged by CBBs that were previously exposed to conidia of $C$. siamense and $C$. tropicale (mixed 1:1, T1) showed significantly higher fruit rot than fruit damaged by CBBs not exposed to conidia (CBB alone, T2) and negative controls of fruit with no damage (T3) $(F=201.8 ; P<0.0001)$ (Fig. 8A). Both fruit damaged by $\mathrm{CBBs}$ exposed to Colletotrichum (T1) and positive

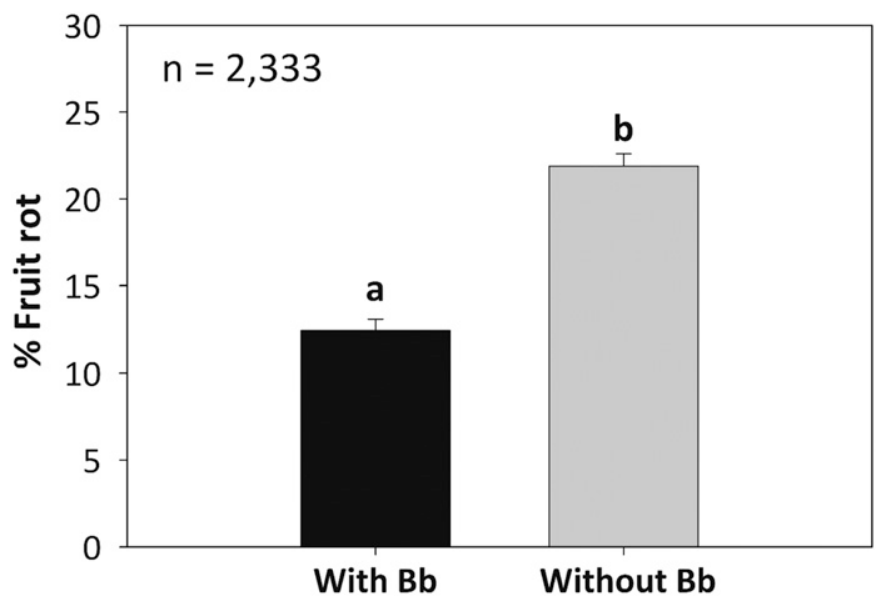

Fig. 3. Mean percent severity of rot in field-collected coffee fruit visibly infected with Beauveria bassiana $(\mathrm{Bb})$ versus noninfected fruit. All fruit had been penetrated by the coffee berry borer. Bars with different letters are statistically different according to Tukey's honest significant differences post hoc test $(\alpha=0.05)$. Bars show +1 standard error. 
controls (T4, fruit manually damaged and inoculated with Colletotrichum) showed fruit rot symptoms, and Colletotrichum was recovered from the diseased fruit. Colletotrichum was not recovered from fruit damaged by $\mathrm{CBBs}$ but not exposed to conidia (T2, Fig. 8B).

In field experiments, the CBBs were exposed to conidia of each Colletotrichum species separately. Similar to the pathogenicity tests described above (see Inoculations with Colletotrichum spp. only), fruit damaged by $\mathrm{CBBs}$ exposed to $C$. tropicale (T4) and $C$. theobromicola (T5) showed significantly more external fruit $\operatorname{rot}(F=9.60 ; P<0.0001)$ than fruit damaged by CBBs exposed to $C$. fructicola $(\mathrm{T} 2)$ and $C$. siamense (T3) (and control fruit perforated by CBBs not exposed to any fungus, negative control [T1]) (Fig. 9A). The results rating the severity of internal rots support those from the pathogenicity tests: $C$. theobromicola was the most aggressive and $C$. tropicale the least aggressive. Differences between $C$. theobromicola and the other three species were significant $(F=11.1 ; P<0.0001)$ (Fig. 9B). Colletotrichum was recovered from fruit damaged by CBBs with Colletotrichum but not from fruit damaged by CBBs but not exposed to conidia (Fig. 9C).

\section{DISCUSSION}

The morphological and phylogenetic studies and the pathogenicity tests all confirmed that four Colletotrichum species, C. fructicola, $C$. siamense, $C$. theobromicola, and C. tropicale, cause rot of green coffee fruit in Puerto Rico. Koch's postulates were fulfilled. To the best of our knowledge, this is the first report of
C. theobromicola and C. tropicale causing anthracnose on coffee fruit, although $C$. theobromicola and $C$. siamense have been reported causing anthracnose on coffee leaves in Mexico (Cristóbal-Martínez et al. 2017). C. fructicola and C. siamense were reported causing anthracnose in Thailand (Prihastuti et al. 2009) (Table 1). Our results reaffirm that report.

Pathogenicity tests with $C$. fructicola, $C$. siamense, $C$. theobromicola, and $C$. tropicale showed that all four cause both internal and external rots of green fruit. More severe external fruit rot was caused by $C$. tropicale, $C$. theobromicola, and some isolates of $C$. siamense, while more severe internal fruit rot was caused by C. theobromicola and C. fructicola. Worldwide, previous reports of CBD have described the disease as an external fruit rot with slightly sunken, brown blight lesions on green and ripening fruit (Gaitán et al. 2015; Hocking 1966; Kenny et al. 2012; Nguyen et al. 2010; Omondi et al. 2001; Vermeulen 1970; Waller et al. 1993). Internal fruit rot, as we describe here, is not mentioned in the cited literature. It is likely that internal rot is more common when $\mathrm{CBB}$ damage (or other damage) provides entry to internal tissues, as was found in field-collected fruit with CBB damage, which was also mimicked in the experiments described here.

Colletotrichum spp. can penetrate plant tissues through stomata, wounds or directly through the cuticle via the production of a penetration peg from the appressorium (Kumar et al. 2001; Moraes et al. 2013; Panday et al. 2012; Smith et al. 1999). All Colletotrichum spp. identified in the study produced appressoria in culture, a key structure for fungal penetration of the host. Appressoria may have been responsible for the external fruit rot
A

\section{Colletotrichum fructicola}

B

\section{Colletotrichum siamense}

C

\section{Colletotrichum theobromicola}

\section{D Colletotrichum tropicale}

Colony
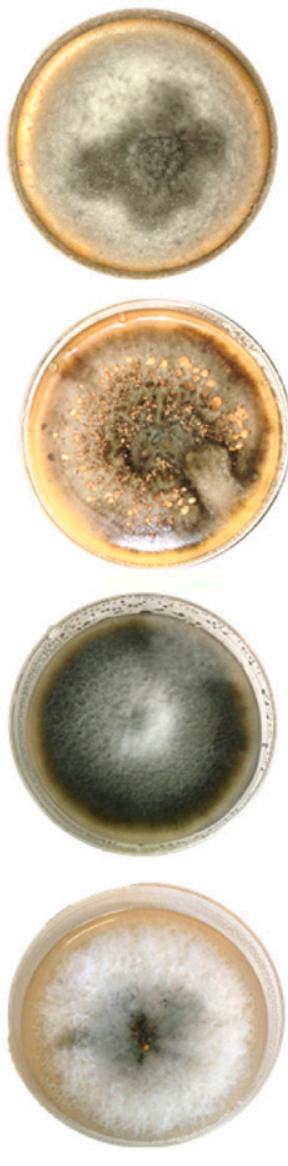

Conidia

Appressoria

Ascospores

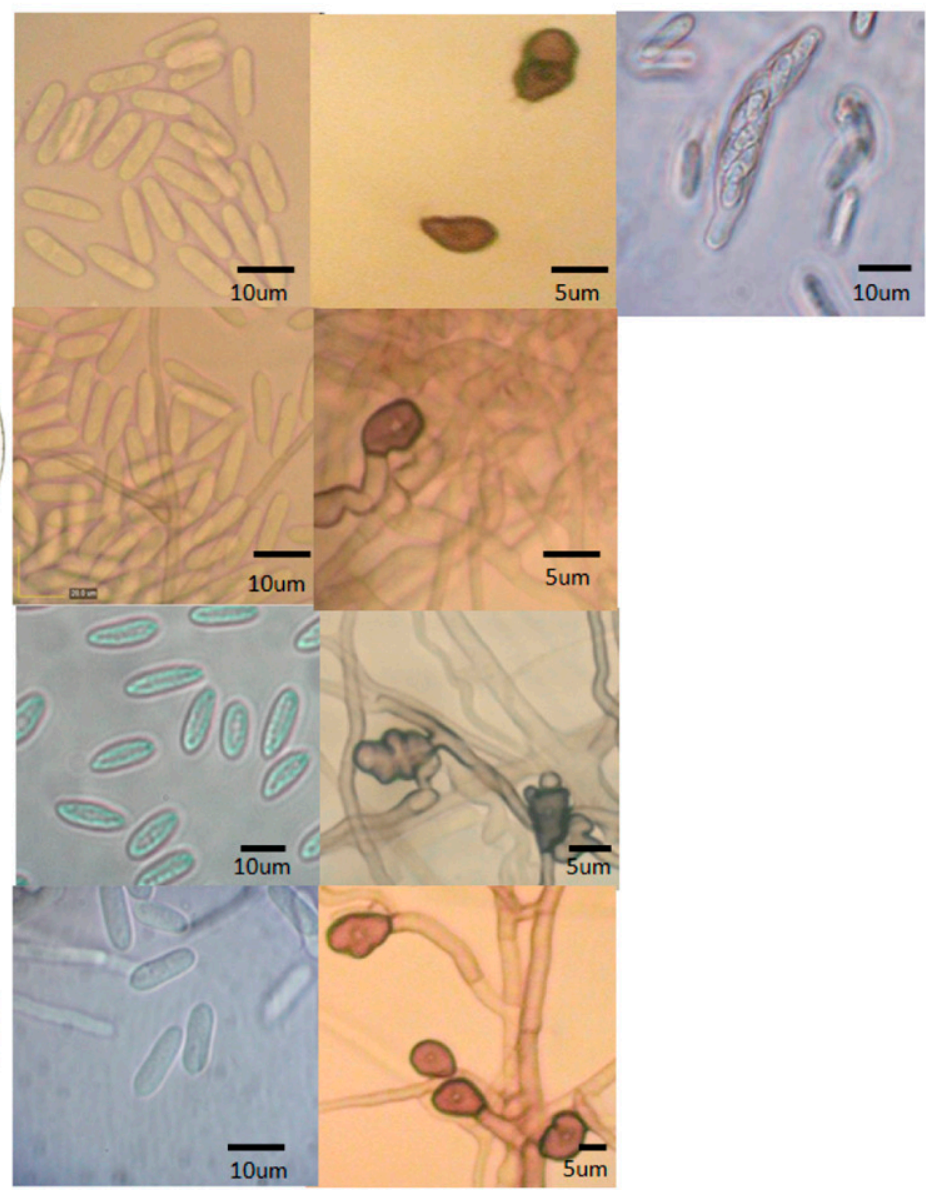

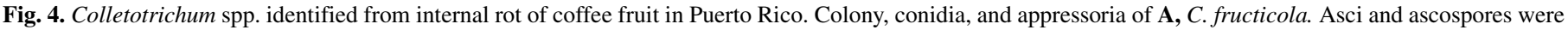
observed only for $C$. fructicola, B, C. siamense, $\mathbf{C}, C$. theobromicola, and $\mathbf{D}, C$. tropicale. 


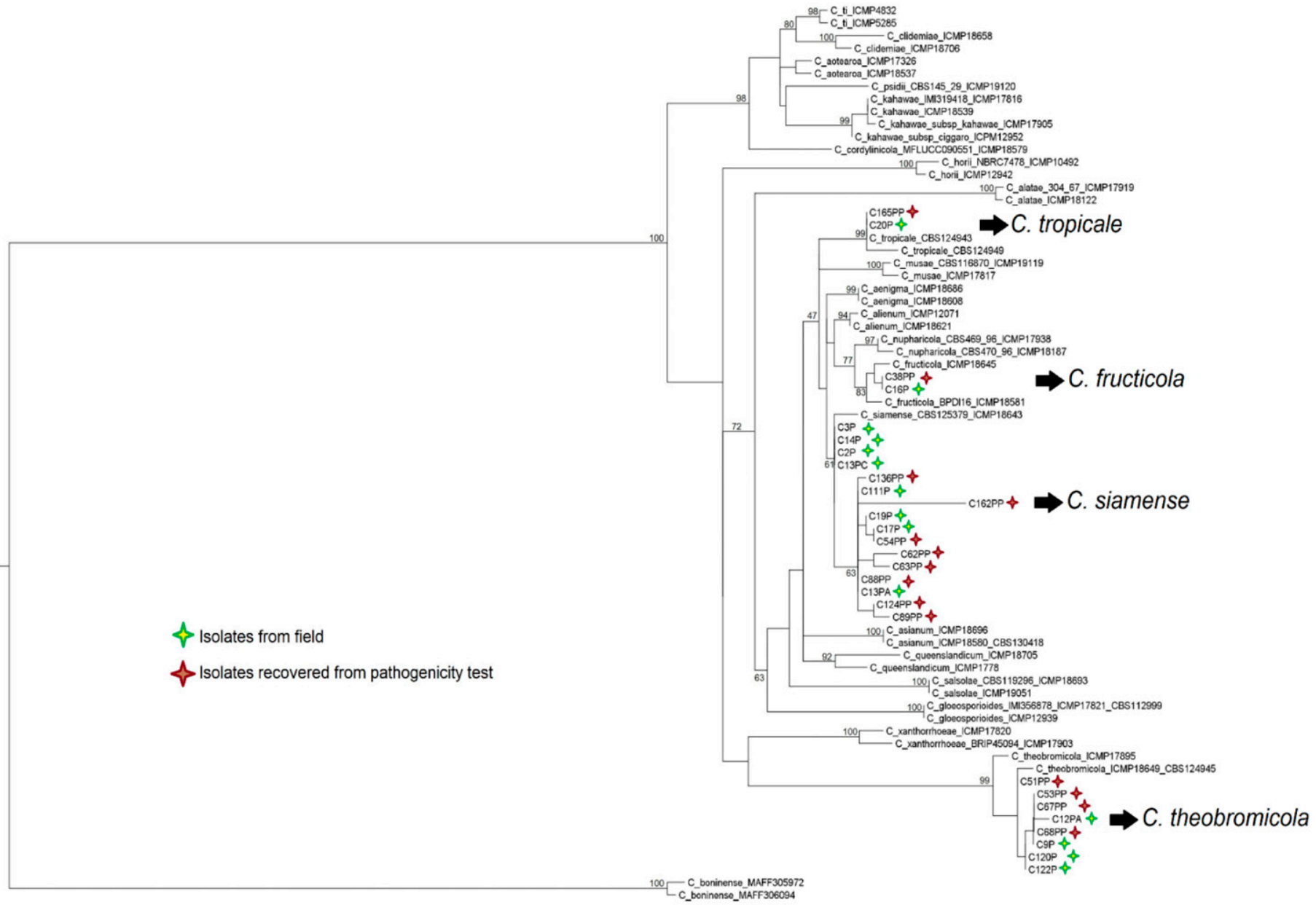

Fig. 5. Maximum likelihood tree of different Colletotrichum species based on the concatenated sequences of internal transcribed spacer, chitin synthase, and glyceraldehyde 3-phosphate dehydrogenase genes. Bootstrap support values are shown at the nodes. Isolates from coffee fruit collected in the field in Puerto Rico and isolates recovered from pathogenicity tests are indicated by colored star symbols. The tree was rooted to the outgroups $C$. boninense ex-type MAFF306094 and MAFF305972.

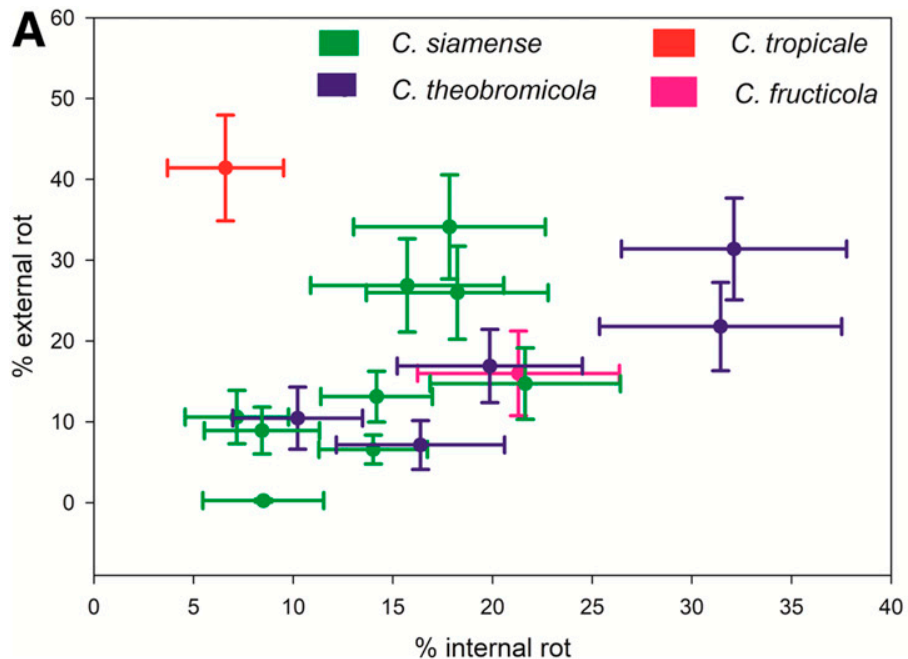

B

C. tropicale
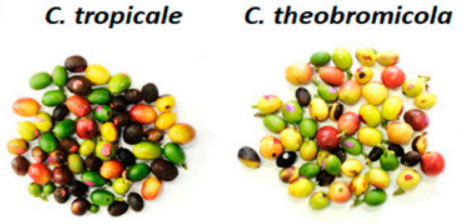

C. siamense
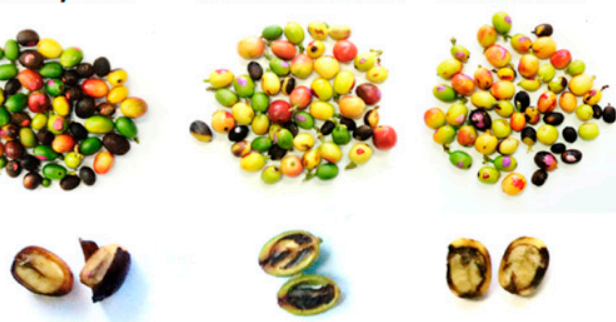

C. fructicola
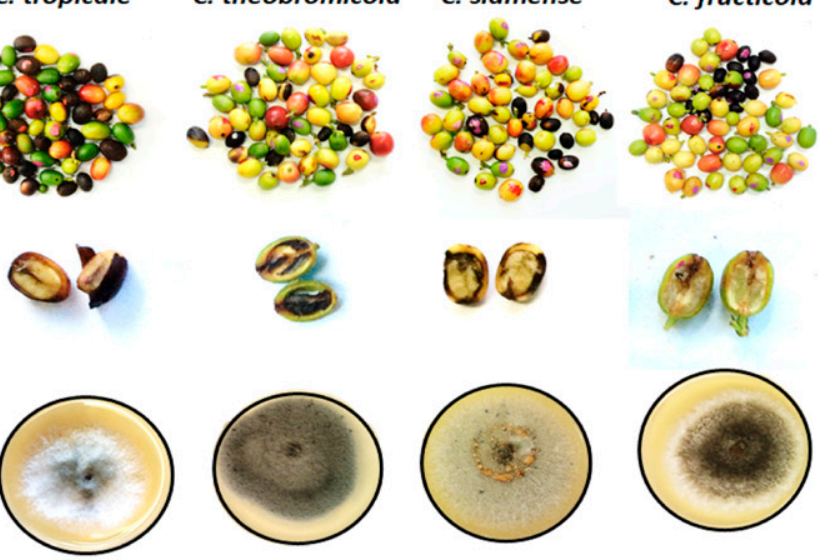

Fig. 6. Internal and external fruit rot of coffee caused by four species of Colletotrichum isolated from diseased fruit in Puerto Rico. A, Mean percent internal and external fruit rot caused by each isolate of $C$. siamense, $C$. theobromicola, $C$. tropicale, and $C$. fructicola is indicated. Bars show \pm 1 standard error. B, Coffee fruit rot/anthracnose symptoms on fruit inoculated with each species of Colletotrichum (top), external and internal fruit rots (center), and isolates recovered after pathogenicity tests (bottom). 
observed, but we did not study this. A penetration peg from the appressorium of $C$. kahawae can generate $2.6 \mathrm{Mpa}$, about twice the osmotic pressure of green coffee fruit, and this mechanical pressure is enough to break the cuticle (Chen et al. 2004).

This study demonstrates that coffee fruit rot is a disease complex caused by several Colletotrichum species, some of which cause more external rot and others more internal rot. This suggests the possibility of differences in ecological niches among the species in the complex, perhaps related to differences in their modes of infection. Inoculation experiments on intact fruits are needed to better understand interactions and differences among these pathogens.

In experiments in both the lab and field, inoculation with $B$. bassiana protected coffee fruit from rot caused by Colletotrichum.
Previous studies have reported that $B$. bassiana inhibits various phytopathogenic fungi (Culebro-Ricaldi et al. 2017; Ownley et al. 2000, 2004, 2010; Sanivada and Challa 2014). B. bassiana produces chitinases and secondary metabolites (i.e. beauvericin, beauverolides, bassianolides, oosporein, cyclosporin A, and oxalic acid) with antifungal, antibacterial, and insecticidal activities (Ownley et al. 2010). Protection by B. bassiana against Colletotrichum may be due to a combination of secondary metabolites and physical exclusion by colonization of plant tissue. B. bassiana has been reported as an endophyte of coffee (Vega et al. 2010) and is common on coffee farms in Puerto Rico (Gallardo et al. 2010).

There are many examples of insects that act as dispersal agents of plant pathogens, including viruses, bacteria, and fungi

\section{$\square$ T1 (Perforated fruit + B.bassiana)

A
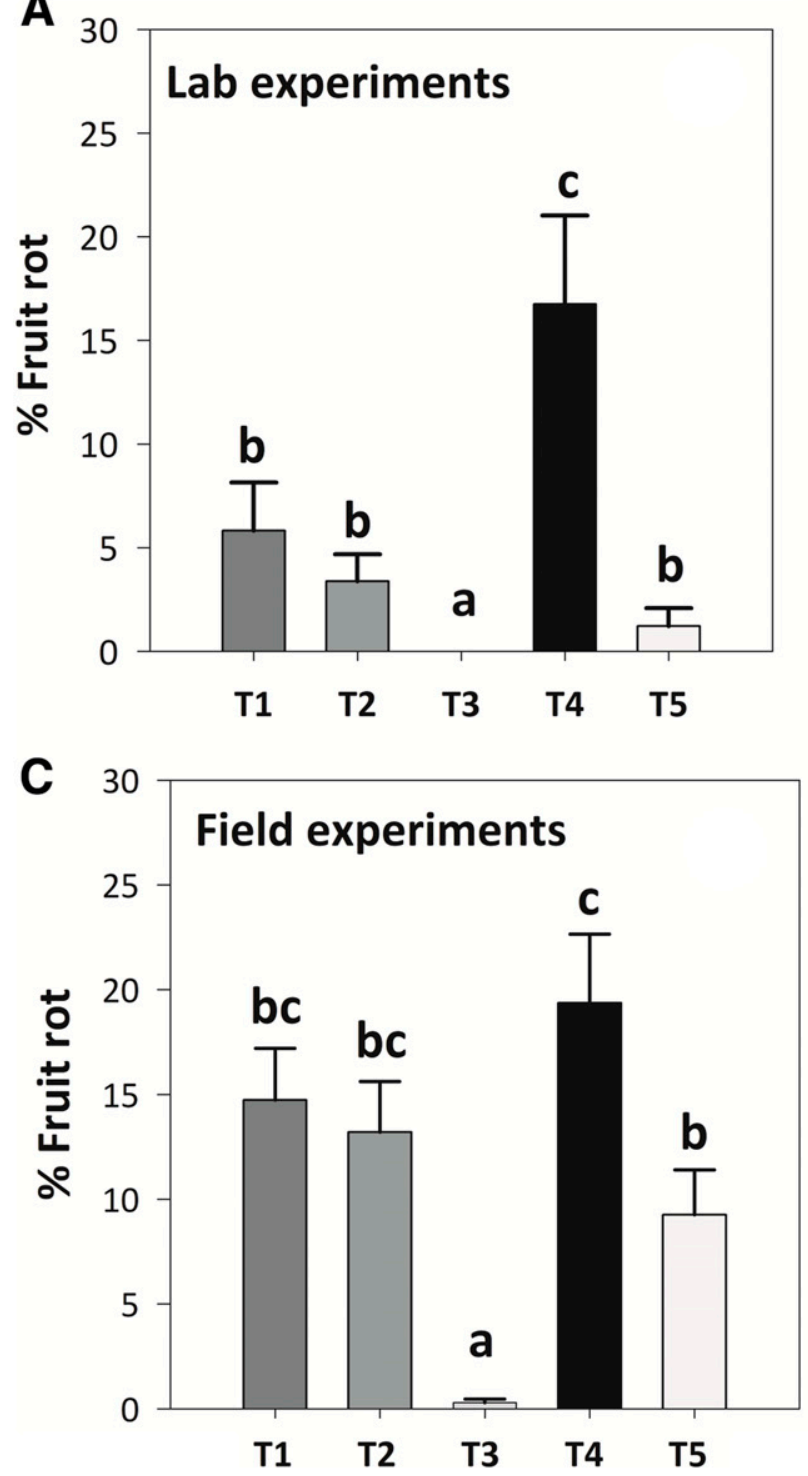

B
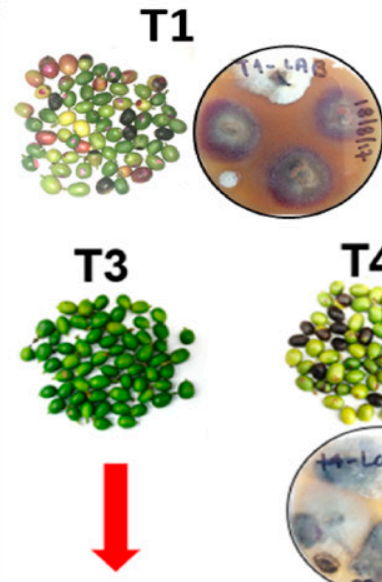

No Fruit Rot

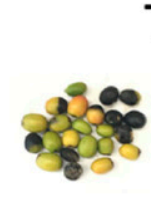

T2

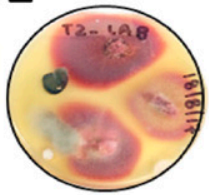

T4

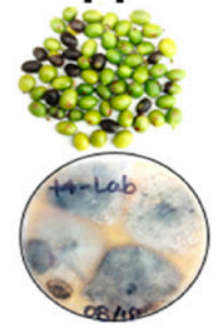

Colletotrichum

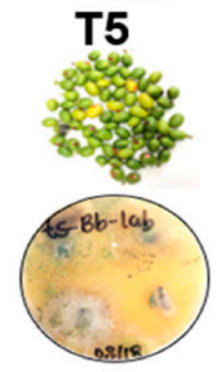

No Colletotrichum

D

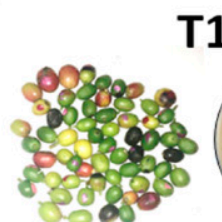

T1
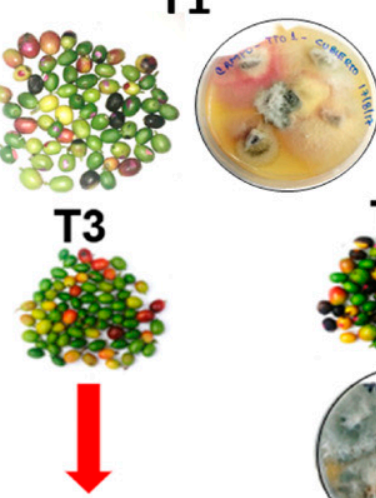

No Fruit Rot

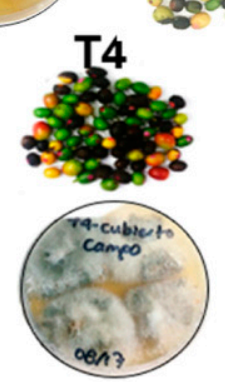

Colletotrichum
T2
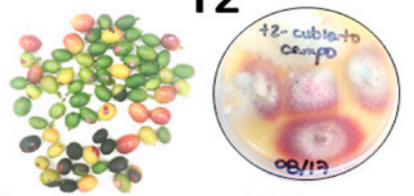

T5
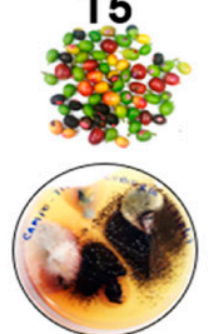

No Colletotrichum

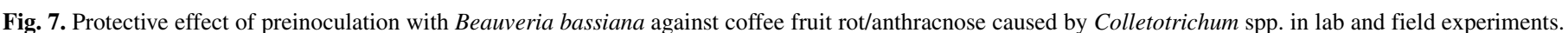

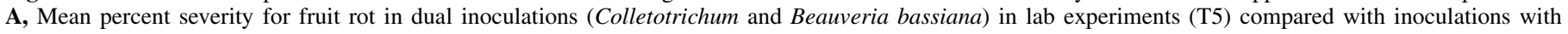

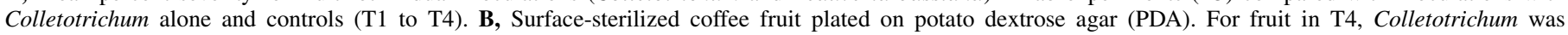

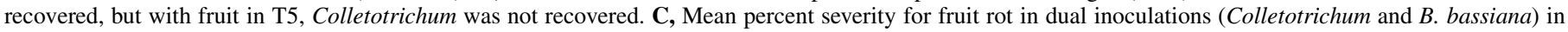

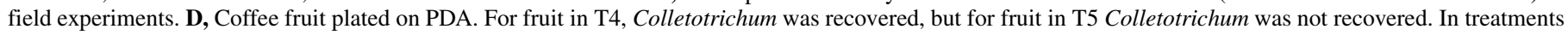

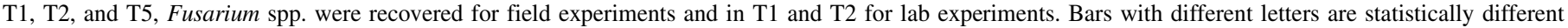
according to Tukey's honest significant differences post hoc test $(\alpha=0.05)$. Error bars show +1 standard error. 
(Eigenbrode et al. 2018; Perilla-Henao and Casteel 2016). For example, bark beetles of the genus Scolytus (mainly S. scolytus and $S$. multistriatus, in the same family as CBB) are vectors of the fungus Ophiostoma ulmi, causal agent of Dutch elm disease (Faccoli and Santini 2016). In our experiments, when CBBs were exposed to conidia of Colletotrichum spp. and subsequently given access to coffee fruit, the fruit became diseased (Fig. 9), indicating that $\mathrm{CBB}$ can be a dispersal agent of coffee fruit pathogens. Although Colletotrichum was isolated from internal tissues after infestation with Colletotrichum-exposed CBBs, external rots were significantly more common, suggesting that Colletotrichum conidia are left on the fruit surfaces as well as carried into the mesocarp. Several studies have shown that CBBs can carry fungal spores: masses of conidia of Penicillium brocae and several unknown fungi have been found on the head and ventral parts of the abdomen, especially at the base of setae and asperites (Carrión and Bonet 2004; Peterson et al. 2003). The internal fruit rot caused by Colletotrichum in coffee may be facilitated by perforations left by $\mathrm{CBB}$; conidia may be transported through the perforation into the fruit by wind or water, or be carried by the CBB itself. The CBB bores a single hole, approximately $0.78 \mathrm{~mm}$ in diameter in each coffee fruit using its mandibles (Vega et al. 2019). Normally, there is a single hole per fruit, but this hole reaches the endosperm and provides entry to internal tissues (Damon 2000).

C. kahawae is regarded in the literature as the sole pathogen causing CBD: "Coffee berry disease is confined to date to the African continent and is the major economic threat to the production of arabica coffee normally growing at high altitudes...." (Gaitán et al. 2015). It can cause losses of up to $80 \%$, due to "....its unparalleled adaptation of infecting green coffee berries" (Silva et al. 2012). C. kahawae is ".... a specialist pathogen with the ability to infect green coffee berries, an ecological niche previously unoccupied by other fungi" (Vieira et al. 2019). It is characterized by dark or pale, sunken lesions or anthracnose on fruit, which can progress to sporulation, fruit drop or mummification (Gaitán et al. 2015; Waller et al. 1993).
Various Colletotrichum species attack a wide spectrum of fruit, ripe and unripe, and the number of fruit available on coffee farms present a resource for any species that can colonize them and sporulate. Thus, it is not surprising that species of Colletotrichum other than $C$. kahawae subsp. kahawae have the capacity to infect and rot green coffee fruit causing typical symptoms of anthracnose and additional external and internal rot symptoms. It has been proposed that $C$. kahawae made a recent host jump to coffee in Africa, where coffee originated (Silva et al. 2012). Coffee was introduced to other parts of the world and planted on a large scale (Bigger 2006), and so it is reasonable to speculate that other Colletotrichum species may have made coffee fruit a new host tissue once the plant became available (Kenny et al. 2012; Nguyen et al. 2010; Prihastuti et al. 2009). Likewise, it is not surprising that a complex of Colletotrichum species cause coffee fruit rots, since this has been shown for other fruit diseases (Serrato-Diaz et al. 2017; Serrato-Diaz et al. 2020). Our results indicate niche differentiation among species of Colletotrichum infecting coffee fruit in Puerto Rico; some species caused more external rot and others more internal rot. These species were included in the $C$. gloeosporioides complex and were recently described as separate species based on DNA sequence data (Weir et al. 2012). Furthermore, it is likely that fungi other than Colletotrichum also cause rots of coffee fruit, although there are few reports in the literature: in one field experiment, Fusarium was frequently isolated from control fruit and fruit inoculated with Colletotrichum (Fig. 8).

C. kahawae was not isolated in this study and has never been reported from Puerto Rico. As noted, other Colletotrichum species were isolated from green fruit with anthracnose lesions and caused rot when inoculated either artificially or through CBB into green coffee fruit, fulfilling Koch's postulates for pathogenicity. Furthermore, they caused internal as well as external rots; internal rot has not been reported previously in relation to pathogens of coffee fruit. The term "coffee berry disease" should not be used for these rots, since by convention its use is restricted to the disease caused by C. kahawae on coffee in Africa (Gaitán et al. 2015). However, all the

\section{A}
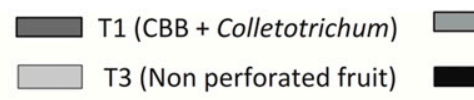

T2 (CBB alone)

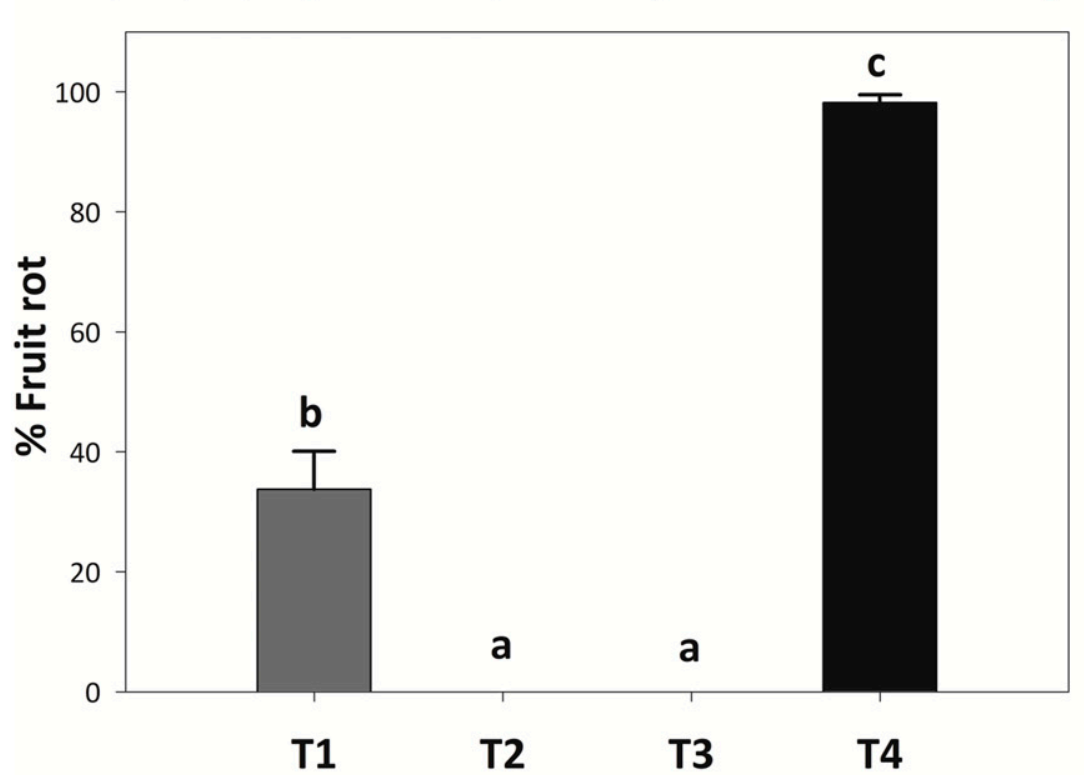

B
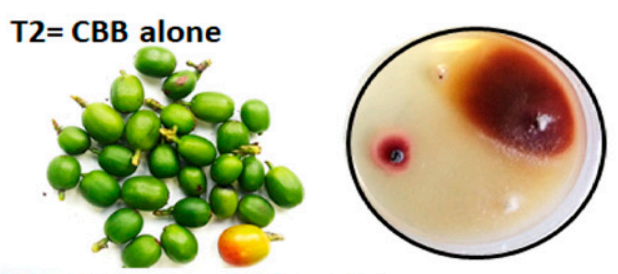

$\mathrm{T1}=\mathrm{CBB}+$ two Colletotrichum
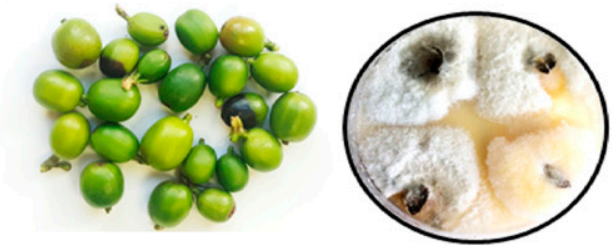

T4= Perforated fruits + two Colletotrichum
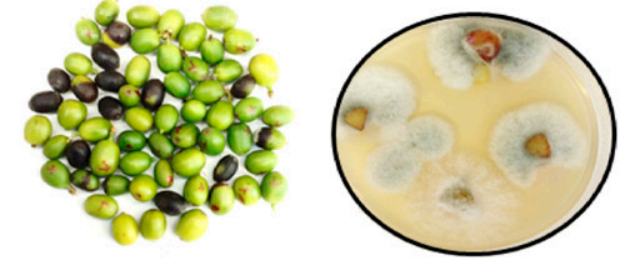

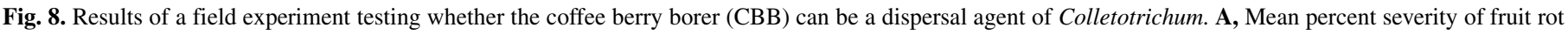

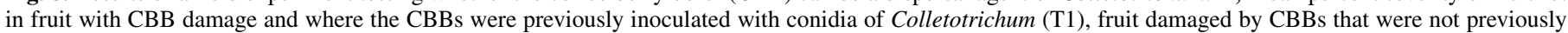

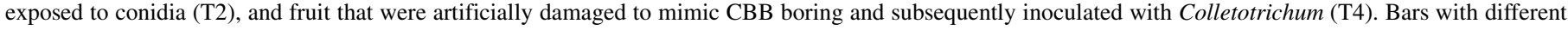

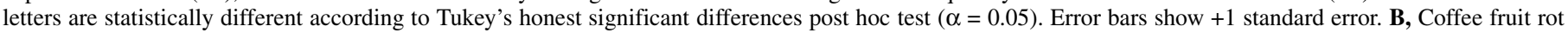

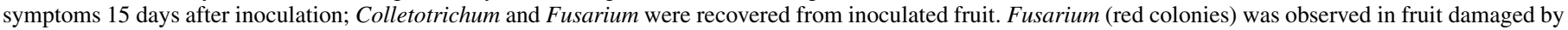
CBBs but not exposed to Colletotrichum (CBB alone, T2). 
symptoms described for CBD caused by C. kahawae in Africa were also observed in this study (Batista et al. 2017). These symptoms include rotting of green coffee fruit, eventually resulting (in advanced stages) in black and mummified fruit.

The literature on CBD has focused on a single pathogen on a single continent, for historical reasons and also because of its alarming virulence (Batista et al. 2017). The data presented here indicate that the relationships among coffee fruit diseases, their symptoms, and the fungal species that cause them may be much more complex than previously considered. We predict they will be found in most coffee-growing areas with high humidity. Their distribution, identification, incidence, and effect on yield should be studied, both in and out of Africa. Furthermore, phytosanitary regulations implemented to prevent the spread of $C$. kahawae out of Africa may be ineffective if they overlook pathogens causing the same symptoms that are already present in other countries such as Vietnam and Thailand (Nguyen et al. 2010; Prihastuti et al. 2009).

Greater awareness of anthracnose among plant pathologists, agricultural extension agents, and coffee farmers is needed, and could reduce losses in coffee yields and quality. In Puerto Rico, there are no management practices for anthracnose because the growers do not yet recognize it as a disease, as stated above. Indeed, farmers and agricultural extensionists have told us that the fruit rot we describe was caused by sun damage or poor plant nutrition, rather than a pathogen. Fertilization and fungicides were reported to reduce anthracnose substantially but not completely (Mignucci et al.1985). There may be abiotic factors that contribute to the disease, but identification and recognition of the pathogens involved will be critical for its future control.

Conclusions. We have provided evidence that the $\mathrm{CBB}$ could be a dispersal agent of coffee fruit pathogens. The possible dual use of B. bassiana against CBB and coffee fruit rot could help famers by (i) reducing the applications of different products if one product containing $B$. bassiana helps control a pest and a disease simultaneously, and (ii) indirectly reduces the damage caused by Colletotrichum by controlling the CBB.

Anthracnose of coffee fruit is complex and consists of both external and internal rots, caused by different Colletotrichum

\section{$\mathrm{T} 2(\mathrm{CBB}+$ C. fructicola)}

\section{$\mathrm{T} 3(\mathrm{CBB}+\mathrm{C}$. siamense $)$}

$$
\mathrm{T} 5 \text { (CBB + C. theobromicola) }
$$ \\ $\mathrm{T} 4(\mathrm{CBB}+\mathrm{C}$. tropicale) $\mathrm{T} 5(\mathrm{CBB}+\mathrm{C}$. theobromicola)}

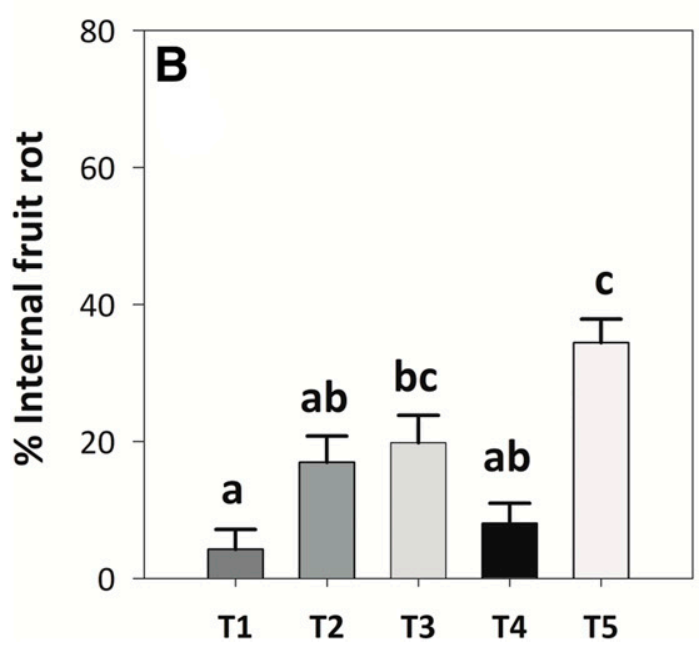

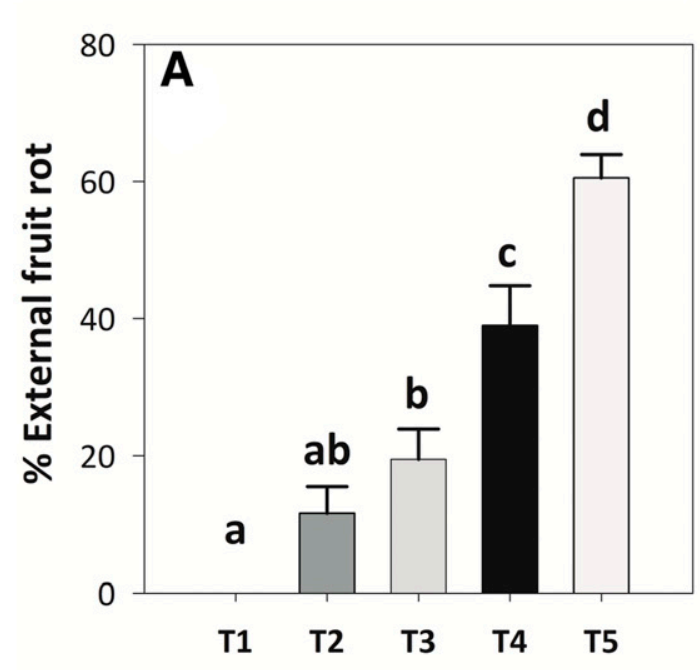

Fig. 9. Results of a field experiment testing whether the coffee berry borer (CBB) was a dispersal agent of Colletotrichum spp. to green coffee fruit. A, Mean percent severity of external fruit rot in coffee fruit damaged by CBBs previously exposed or not exposed to different Colletotrichum spp. Error bars show +1 standard error. B, Mean percent internal fruit rot in coffee fruit damaged by CBBs previously exposed or not exposed to different Colletotrichum spp. Bars with different letters are statistically different according to Tukey's honest significant differences post hoc test $(\alpha=0.05)$. C, Coffee fruit 15 days after inoculation; Colletotrichum spp. recovered after exposure of fruit to CBBs (C. fructicola, C. siamense, C. tropicale, and C. theobromicola, respectively). 
pathogens. Our results suggest further that Fusarium spp. also play a role in some coffee fruit rots. Studies with Fusarium spp. are needed to better understand the disease in the field and the role of the CBB as a dispersal agent under natural conditions.

\section{ACKNOWLEDGMENTS}

We thank the personnel at the Agricultural Experimental Station in Adjuntas, PR for permission to work there, especially Fernando Gallardo and Jennifer Pagán. We thank Victor Vega, Omar Oduardo, Alejandro Soto, Rocio Rivera and Joselyn de Jesús for their invaluable help in lab and fieldwork; an anonymous reviewer for extensive, useful, and thoughtful comments; and the University of Puerto Rico sequencing and genotyping facility (UPR-SGF).

\section{LITERATURE CITED}

Agrios, G. 1997. Plant disease caused by fungi. Pages 324-331 in: Plant Pathology. Academic Press, San Diego, CA.

Aristizábal, L., Johnson, M., Shriner, S., Hollingsworth, R., Manoukis, N., Myers, R., Bayman, P., and Arthurs, S. 2017. Integrated pest management of coffee berry borer in Hawaii and Puerto Rico: Current status and prospects. Insects $8: 123$.

Balardin, R., Jarosz, A., and Kelly, J. 1997. Virulence and molecular diversity in Colletotrichum lindemuthianum from South, Central, and North America. Phytopathology 87:1184-1191.

Barnett, H. L., and Hunter, B. B. 1998. Illustrated Genera of Imperfect Fungi, 4th ed. American Phytopathological Society, St. Paul, MN.

Batista, D., Silva, D. N., Vieira, A., Cabral, A., Pires, A., Loureiro, A., Guerra-Guimarães, L., Pereira, A. P., Azinheira, H., and Talhinhas, P. 2017. Legitimacy and implications of reducing Colletotrichum kahawae to subspecies in plant pathology. Front. Plant Sci. 7:2051.

Bigger, M. 2006. The dissemination of coffee cultivation throughout the world. Trop. Agric. Assoc. Newsl. 26:15-19.

Birikunzira, J. B. 2000. Recent advances in coffee berry disease (CBD) control in Uganda. Uganda J. Agric. Sci. 5:57-60.

Bliss, C. 1937. The analysis of field experimental data expressed in percentages. Plant Prot. 12:67-77.

Carbone, I., and Kohn, L. 1999. A method for designing primer sets for speciation studies in filamentous ascomycetes. Mycologia 91:553-556.

Carrión, G., and Bonet, A. 2004. Mycobiota associated with the coffee berry borer (Coleoptera: Scolytidae) and its galleries in fruit. Ann. Entomol. Soc. Am. 97:492-499.

Chen, Z., Nunes, M. A., Silva, M. C., and Rodrigues, C. J., Jr. 2004. Appressorium turgor pressure of Colletotrichum kahawae might have a role in coffee cuticle penetration. Mycologia 96:1199-1208.

Costa, J. N., Garcia, A., Ribeiro, P., and da Silva, R. B. 2002. Ocorrência de Beauveria bassiana (Bals) Vuill., em broca-do-café (Hypothenemus hampei, Ferrari) no estado de Rondônia, Brasil. Acta Amazon. 32:517-519.

Cristóbal-Martínez, A. L., Yáñez-Morales, M., Solano-Vidal, R., Segura-León, O., and Hernández-Anguiano, A. M. 2017. Diversity of Colletotrichum species in coffee (Coffea arabica) plantations in Mexico. Eur. J. Plant Pathol. 147:605-614.

Culebro-Ricaldi, J., Ruíz-Valdiviezo, V., Rodríguez-Mendiola, M., Ávila-Miranda, M., Miceli, F. G., Cruz-Rodríguez, R., Dendooven, L., and Montes-Molina, J. 2017. Antifungal properties of Beauveria bassiana strains against Fusarium oxysporum f. sp. lycopersici race 3 in tomato crop. J. Environ. Biol. 38:821.

Damon, A. 2000. A review of the biology and control of the coffee berry borer, Hypothenemus hampei (Coleoptera: Scolytidae). Bull. Entomol. Res. 90:453-465.

De La Rosa, W., Alatorre, R., Barrera, J., and Toriello, C. 2000. Effect of Beauveria bassiana and Metarhizium anisopliae (Deuteromycetes) upon the coffee berry borer (Coleoptera: Scolytidae) under field conditions. J. Econ. Entomol. 93:1409-1414.

Denoyes-Rothan, B., Guérin, G., Délye, C., Smith, B., Minz, D., Maymon, M., and Freeman, S. 2003. Genetic diversity and pathogenic variability among isolates of Colletotrichum species from strawberry. Phytopathology 93: 219-228.

Eigenbrode, S. D., Bosque-Pérez, N. A., and Davis, T. S. 2018. Insect-borne plant pathogens and their vectors: Ecology, evolution, and complex interactions. Annu. Rev. Entomol. 63:169-191.

Etana, M. 2018. Review on the management of coffee berry disease (Colletotrichum kahawae) in Ethiopia. Food Sci. Qual. Manage. 78:73-76.

Faccoli, M., and Santini, A. 2016. Dutch elm disease and elm bark beetles: Pathogen-insect interaction. Pages 73-86 in: Vector-Mediated Transmission of Plant Pathogens. American Phytopathology Society, St. Paul, MN.

Gaitán, A. L., Cristancho, M. A., Caicedo, B. C., Rivillas, C. A., and Gómez, G. C. 2015. Compendium of Coffee Diseases and Pests. American Phytopathological Society, St. Paul, MN.
Gallardo, F., and González, O. 2015. Manejo integrado de la broca del café en Puerto Rico. Guía Técnica. Departamento de Agricultura, San Juan, Puerto Rico.

Gallardo, F., Hernández, E., and Pagán, J. 2010. Presencia natural del hongo Beauveria bassiana (Bals.) Vuill. en la broca del café Hypothenemus hampei (Ferrari) en Puerto Rico. J. Agric. Univ. Puerto Rico 1-2:195-198.

Haraprasad, N., Niranjana, S., Prakash, H., Shetty, H., and Wahab, S. 2001. Beauveria bassiana-a potential mycopesticide for the efficient control of coffee berry borer, Hypothenemus hampei (Ferrari) in India. Biocontrol Sci. Technol. 11:251-260.

Hocking, D. 1966. Brown blight (Colletotrichum coffeanum Noack.) of arabica coffee in East Africa. Ann. Appl. Biol. 58:409-421.

Hong, S. K., Kim, W. G., Yun, H. K., and Choi, K. J. 2008. Morphological variations, genetic diversity and pathogenicity of Colletotrichum species causing grape ripe rot in Korea. Plant Pathol. J. 24:269-278.

Infante, F., Pérez, J., and Vega, F. 2014. The coffee berry borer: The centenary of a biological invasion in Brazil. Braz. J. Biol. 74:S125-S126.

Jaramillo, J., Borgemeister, C., and Baker, P. 2006. Coffee berry borer Hypothenemus hampei (Coleoptera: Curculionidae): Searching for sustainable control strategies. Bull. Entomol. Res. 96:223-233.

Katoh, K., and Standley, D. M. 2013. MAFFT Multiple Sequence Alignment Software Version 7: Improvements in performance and usability. Mol. Biol. Evol. 30:772-780.

Kenny, M., Galea, V., and Price, T. 2012. Germination and growth of Colletotrichum acutatum and Colletotrichum gloeosporioides isolates from coffee in Papua New Guinea and their pathogenicity to coffee berries. Australas. Plant Pathol. 41:519-528.

Kumar, V., Gupta, V., Babu, A., Mishra, R., Thiagarajan, V., and Datta, R. 2001. Surface ultrastructural studies on penetration and infection process of Colletotrichum gloeosporioides on mulberry leaf causing black spot disease. J. Phytopathol. 149:629-633.

Maldonado, C., Angel, L., Florez, C., Angel, C., and Gaitan, A. 2017. Page 72 in: The Colombian Strategy Against Devastating Coffee Diseases: Preparation for Coffee Berry Disease (Colletotrichum kahawae subsp. kahawae). American Phytopathological Society, St. Paul, MN.

Mariño, Y. A., Vega, V. J., García, J. M., Verle Rodrigues, J. C., García, N. M., and Bayman, P. 2017a. The coffee berry borer (Coleoptera: Curculionidae) in Puerto Rico: Distribution, infestation, and population per fruit. J. Insect Sci. 17:58.

Mariño, Y. A., Verle Rodrigues, J. C., and Bayman, P. 2017b. Wolbachia affects reproduction and population dynamics of the coffee berry borer (Hypothenemus hampei): Implications for biological control. Insects 8:8.

Mignucci, J., Hepperly, P., Ballester, J., and Rodríguez-Santiago, C. 1985. Anthracnose and berry disease of coffee in Puerto Rico. J. Agric. Univ. Puerto Rico 69:107-117.

Miller, M. A., Pfeiffer, W., and Schwartz, T. 2010. Creating the CIPRES Science Gateway for inference of large phylogenetic trees. Pages 1-8 in: Gateway Computing Environments Workshop (GCE), New Orleans, LA.

Moraes, S. R. G., Tanaka, F. A. O., and Massola Júnior, N. S. 2013. Histopathology of Colletotrichum gloeosporioides on guava fruits (Psidium guajava L.). Rev. Bras. Frutic. 35:657-664

Nguyen, P. T. H., Pettersson, O. V., Olsson, P., and Liljeroth, E. 2010. Identification of Colletotrichum species associated with anthracnose disease of coffee in Vietnam. Eur. J. Plant Pathol. 127:73-87.

Omondi, C., Ayiecho, P., Mwang'ombe, A. W., and Hindorf, H. 2001. Resistance of Coffea arabica cv. Ruiru 11 tested with different isolates of Colletotrichum kahawae, the causal agent of coffee berry disease. Euphytica 121:19-24.

Ownley, B., Bishop, D., and Pereira, R. 2000. Biocontrol of Rhizoctonia damping-off of tomato with Beauveria bassiana. (Abstr.) Phytopathology 90(suppl.):S58.

Ownley, B. H., Griffin, M. R., Klingeman, W. E., Gwinn, K. D., Moulton, J. K., and Pereira, R. M. 2008. Beauveria bassiana: endophytic colonization and plant disease control. J. Invertebr. Pathol. 98:267-270.

Ownley, B. H., Gwinn, K. D., and Vega, F. E. 2010. Endophytic fungal entomopathogens with activity against plant pathogens: Ecology and evolution. BioControl 55:113-128.

Ownley, B. H., Pereira, R. M., Klingeman, W. E., Quigley, N. B., and Leckie, B. M. 2004. Beauveria bassiana, a dual purpose biocontrol organism, with activity against insect pests and plant pathogens. Pages 255-269 in: Emerging Concepts in Plant Health Management Research, Signpost, India.

Panday, S., Alberto, R., and Labe, M. 2012. Ultrastructural characterization of infection and colonization of Colletotrichum gloeosporioides in onion. Plant Pathol. Quarant. 2:168-177.

Perilla-Henao, L. M., and Casteel, C. L. 2016. Vector-borne bacterial plant pathogens: Interactions with hemipteran insects and plants. Front. Plant Sci. 7:1163.

Peterson, S. W., Pérez, J., Vega, F. E., and Infante, F. 2003. Penicillium brocae, a new species associated with the coffee berry borer in Chiapas, Mexico. Mycologia 95:141-147. 
Prihastuti, H., Cai, L., Chen, H., McKenzie, E., and Hyde, K. 2009. Characterization of Colletotrichum species associated with coffee berries in northern Thailand. Fungal Divers. 39:89-109.

R Core Team. 2017. R: A language and environment for statistical computing. Version 3.4.3. R Core Team, Vienna, Austria. http://www.R.project.org/

Ratanacherdchai, K., Wang, H., Lin, F., and Soytong, K. 2007. RAPD analysis of Colletotrichum species causing chili anthracnose disease in Thailand. J. Agric. Technol. 3:211-219.

Sahab, A. F. 2012. Antimicrobial efficacy of secondary metabolites of Beauveria bassiana against selected bacteria and phytopathogenic fungi. J. Appl. Sci. Res. 8:1441-1444.

Sanivada, S. K., and Challa, M. 2014. Mycolytic effect of extracellular enzymes of entomopathogenic fungi to Colletotrichum falcatum, red rot pathogen of sugarcane. J. Biopesticides 7:33-37.

Serrato-Diaz, L., Rivera, L., Goenaga, R., Navarro, E., and French-Monar, R. 2017. First report of Colletotrichum fructicola and C. queenslandicum causing fruit rot of rambutan (Nephelium lappaceum). Plant Dis. 101:1043.

Serrato-Diaz, L. M., Mariño, Y. A., Guadalupe, I., Bayman, P., and Goenaga, R. 2020. First report of Lasiodiplodia pseudotheobromae and Colletotrichum siamense causing cacao pod rot, and first report of $C$. tropicale causing cacao pod rot in Puerto Rico. Plant Dis. 104:592.

Silva, D. N., Talhinhas, P., Cai, L., Manuel, L., Gichuru, E. K., Loureiro, A., Várzea, V., Paulo, O. S., and Batista, D. 2012. Host-jump drives rapid and recent ecological speciation of the emergent fungal pathogen Colletotrichum kahawae. Mol. Ecol. 21:2655-2670.

Smith, J., Korsten, L., and Aveling, T. 1999. Infection process of Colletotrichum dematium on cowpea stems. Mycol. Res. 103:230-234.

Sreenivasaprasad, S., Brown, A. E., and Mills, P. 1993. Coffee berry disease pathogen in Africa: Genetic structure and relationship to the group species Colletotrichum gloeosporioides. Mycol. Res. 97:995-1000.

Stamatakis, A. 2006a. RAxML-VI-HPC: Maximum likelihood-based phylogenetic analyses with thousands of taxa and mixed models. Bioinformatics $22: 2688-2690$

Stamatakis, A. 2006b. Phylogenetic models of rate heterogeneity: A high performance computing perspective. Proceedings 20th IEEE International Parallel \& Distributed Processing Symposium IEEE. Rhodos, Greece.

Talhinhas, P., Batista, D., Diniz, I., Vieira, A., Silva, D. N., Loureiro, A., Tavares, S., Pereira, A. P., Azinheira, H. G., and Guerra-Guimarães, L. 2017. The coffee leaf rust pathogen Hemileia vastatrix: One and a half centuries around the tropics. Mol. Plant Pathol. 18:1039-1051.

Templeton, M. D., Rikkerink, E. H., Solon, S. L., and Crowhurst, R. N. 1992. Cloning and molecular characterization of the glyceraldehyde-3-phosphate dehydrogenase-encoding gene and cDNA from the plant pathogenic fungus Glomerella cingulata. Gene 122:225-230.
Van der Vossen, H., Cook, R., and Murakaru, G. 1976. Breeding for resistance to coffee berry disease caused by Colletotrichum coffeanum Noack (sensu Hindorf) in Coffea arabica L. I. Methods of preselection for resistance. Euphytica 25:733-745.

Vega, F. 2004. Coffee berry borer Hypothenemus hampei (Ferrari) (Coleoptera: Scolytidae). Pages 575-576 in: Encyclopedia of Entomology. J. L. Capinera, ed. Vol. 1. Kluwer Academic Publishers, The Netherlands.

Vega, F. E., Infante, F., Castillo, A., and Jaramillo, J. 2009. The coffee berry borer, Hypothenemus hampei (Ferrari) (Coleoptera: Curculionidae): A short review, with recent findings and future research directions. Terr. Arthropod Rev. 2:129.

Vega, F. E., Infante, F., and Johnson, A. J. 2015. The genus Hypothenemus, with emphasis on H. hampei, the coffee berry borer. Pages 427-494 in: Bark Beetles. Elsevier, London, U.K.

Vega, F. E., Posada, F., and Infante, F. 2006. Coffee insects: Ecology and control. Pages 1-4 in: Encyclopedia of Pest Management, Taylor \& Francis.

Vega, F. E., Simpkins, A., Aime, M. C., Posada, F., Peterson, S. W., Rehner, S. A., Infante, F., Castillo, A., and Arnold, A. E. 2010. Fungal endophyte diversity in coffee plants from Colombia, Hawai'i, Mexico and Puerto Rico. Fungal Ecol. 3:122-138

Vega, F. E., Smith, L., Davies, N., Moat, J., Góral, T., Sullivan, R., and Davis, A. 2019. Elucidation of hosts, native distribution, and habitat of the coffee berry borer (Hypothenemus hampei) using herbaria and other museum collections. Front. Plant Sci. 10:1188.

Vermeulen, H. 1970. Coffee berry disease in Kenya. I. Colletotrichum spp. colonizing the bark of Coffea arabica. Neth. J. Plant Pathol. 76:277.

Vieira, Y., Silva, D. N., Varzea, V. M. P., Paulo, O. S., and Batista, D. 2019. Genome-wide signatures of selection in Colletotrichum kahawae reveal candidate genes potentially involved in pathogenicity and aggressiveness. Front. Microbiol. 10:1374.

Waller, J., Bridge, P., Black, R., and Hakiza, G. 1993. Characterization of the coffee berry disease pathogen, Colletotrichum kahawae sp. nov. Mycol. Res. 97:989-994.

Weir, B., Johnston, P., and Damm, U. 2012. The Colletotrichum gloeosporioides species complex. Stud. Mycol. 73:115-180.

White, T., Bruns, T., Lee, S., and Taylor, J. 1990. Amplification and direct sequencing of fungal ribosomal RNA genes for phylogenetics. Pages 315322 in: PCR Protocols: A Guide to Methods and Applications. Academic Press, San Diego, CA.

Wraight, S., Galaini-Wraight, S., Howes, R., Castrillo, L., Carruthers, R., Smith, R., Matsumoto, T., and Keith, L. 2018. Prevalence of naturallyoccurring strains of Beauveria bassiana in populations of coffee berry borer Hypothenemus hampei on Hawai'i Island, with observations on coffee plant H. hampei-B. bassiana interactions. J. Invertebr. Pathol. 156:54-72. 